\title{
Discussions on disaster risk reduction for Padang City against tsunami by the seawall
}

\author{
Paulus P. Rahardjo ${ }^{1, *}$, Caroline Sutandi ${ }^{1}$, Karyadi Kusliansjah ${ }^{2}$, Pele Widjaja ${ }^{2}$, Aflizal Arafianto ${ }^{1}$, and Stefanus \\ Diaz Alvi ${ }^{1}$ \\ ${ }^{1}$ Civil Engineering, Parahyangan Catholic University, Jl. Ciumbuleuit No. 94, Bandung, 40141, Indonesia \\ ${ }^{2}$ Architecture Department, Parahyangan Catholic University, Jl. Ciumbuleuit No. 94, Bandung, 40141, Indonesia
}

\begin{abstract}
The 30 September 2009 Padang Pariaman (or West Sumatera Earthquake) $(\mathrm{M}=7.6$ USGS) has caused severe damages of buildings and infrastructures and fatalities. Many of the buildings failed may be due to the low quality of the structures or due to that most buildings were designed Indonesian code SNI 1726-2002, and many of them failed because of the occurrence of liquefaction causing foundation failures. However, a future earthquake could have been even more severe and causes a tsunami, a reality which we shall consider, especially because Padang City is located facing directly to the ocean. Based on the occurrence and experience in Banda Aceh, Padang City has similar risk and yet very limited barrier and lack of evacuation system. For evaluation of this issue, a team of Universitas Katolik Parahyangan conducted a preliminary study on the condition of Padang City and discuss some alternatives to be considered by the government or authority. Methods of research are based on a literature study and collected data for analysis. Options are discussed and conclusions are derived. This paper discusses the important lessons from Banda Aceh failures related to the tsunami, and method to reduce the disaster risk for Padang City by Tsunami Seawall. The purpose of this study is to discuss the risk of the tsunami at Padang City, the preparedness and local condition, and alternative actions to be carried out. There has been pro and cons for Seawall, but the study concluded that due to the fact that tsunami would reach the city within 15-30 minutes after the earthquake and condition of low lying elevation of the Padang City, the use of Seawall for city safety is worth to be considered.
\end{abstract}

\section{Introduction}

We still remember tsunami caused by 26 December 2004 earthquake $(\mathrm{Mw}=9.2)$ becoming the largest disaster in the history. More than 280,000 people in Banda Aceh, North Sumatera and other countries including Sri Lanka, Thailand, India, Maldives Island, and even Africa. Now, many researchers and research institution have thought that the next disaster in mind similar to the one in Banda Aceh, may occur along the west coast of Sumatera; among the most critical area in Padang City. The source of the energy for the upcoming earthquakes will be from the Megathrust west of Sumatera.

Some studies have shown that due to the low-lying land of Padang City, the tsunami effect will be more severe, especially along the west coastal area of the city and through the rivers that could reach from 3 to $5 \mathrm{~km}$ inland. This paper will discuss the possible tsunami disaster for Padang City and alternatives available to decrease the disaster risk.

In general, the damages of infrastructures and buildings due to 30 September 2009 in Padang City was very severe. A team of Universitas Katolik Parahyangan Bandung works with local people to identify several building damages in the city in 2009-2010 as depicted in the report [1]. The damages were reported in many media and reports by institutions and most of them focused on the damages of non-engineered or insufficiently engineered buildings. Only a few of them discussed the contribution of the soil conditions as the important factor causing the building failures even though some of them mentioned about the occurrence of liquefaction as witnessed by the people. The authors believed that liquefaction has also provided an important role in the contribution of the collapse of the buildings, not only due to the quality of the structures. Many of the building damage severity have been identified to be located on deep soft soils containing very loose fine sands underline by soft marine clays.

Based on the visual and distribution of the damages, Universitas Katolik Parahyangan conducted drillings and many CPTu tests to investigate the potential of the location to liquefaction. The CPTu tests are regarded as the best tool to identify the phenomena of liquefaction. In addition, Indonesian Institute of Sciences (LIPI) has also conducted drilling in some location for mapping liquefaction potential as discussed in the following section (Fig. 1.). 


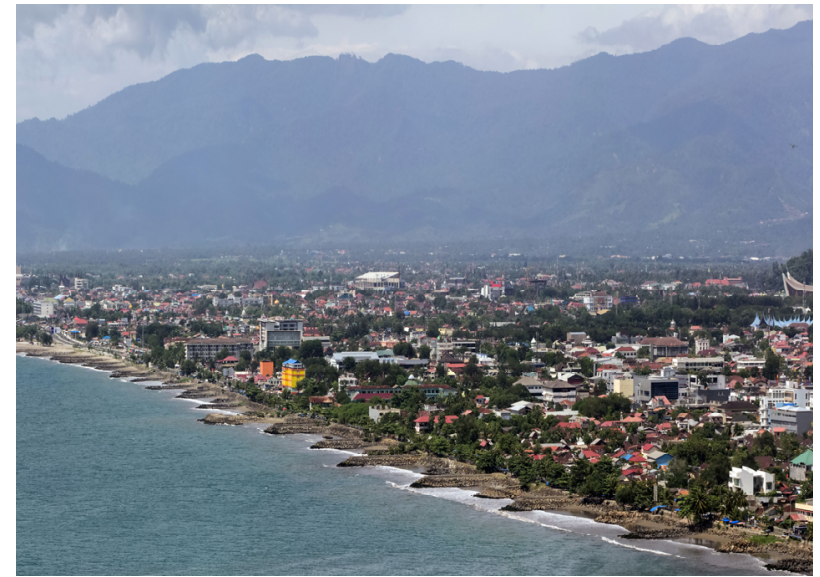

Fig. 1. Padang City showed from the sea [2]

\section{Geology and seismicity of Padang}

The physiography of the Padang City consists of delta plains facing marine sediments, coastal sediments, swamps and alluvium which are geologically deposited in the quaternary period. A study by LIPI (2012) is shown the alluvium consisting of clays and silts and to some extent sands on the surfaces as shown in Fig. 2.

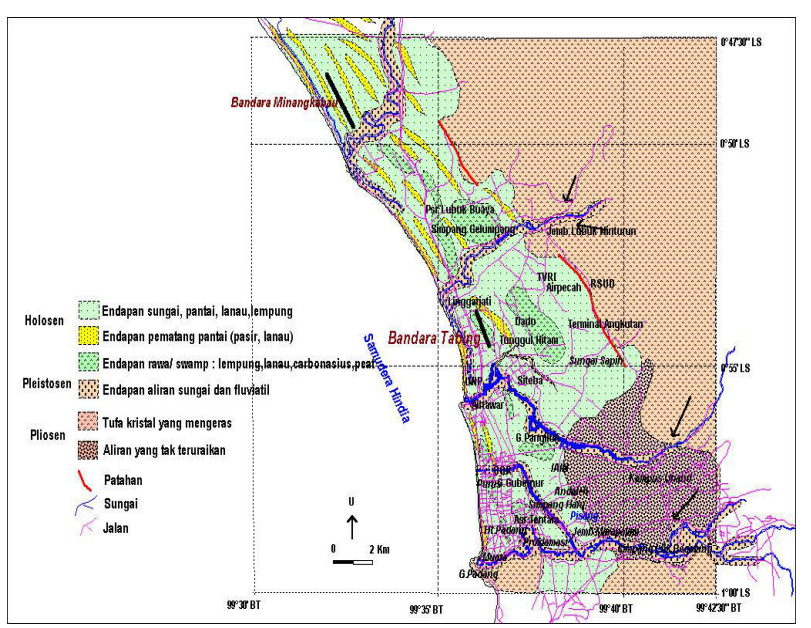

Fig. 2. Geology of Padang City [3]

The west side of Sumatera has been well known as areas with frequent earthquakes due to the position at approximately $250 \mathrm{~km}$ from the subduction zone of the Sumatera and Java Arch. This tectonic plate moves 60$70 \mathrm{~mm}$ annually towards east-north [4]. This zone boundary is known as the zone of seismically active and causing several earthquakes as shown on the seismicity of Sumatera (Fig. 3.). For seismic hazard study, earthquakes data were collected in a stretch of $200 \mathrm{~km}$ cross section long (Fig. 4.) and the results coincide with the subduction of the Indo-Australia plate colliding with the continental Plate of Eurasia [5]. Hence the tectonic process is the responsible element for the seismicity of the region.

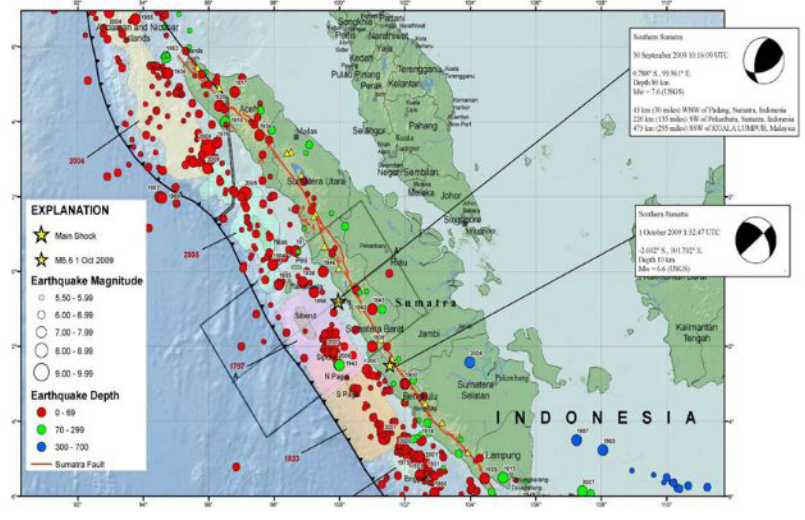

Fig. 3. Seismicity of Sumatera and Padang City [4]

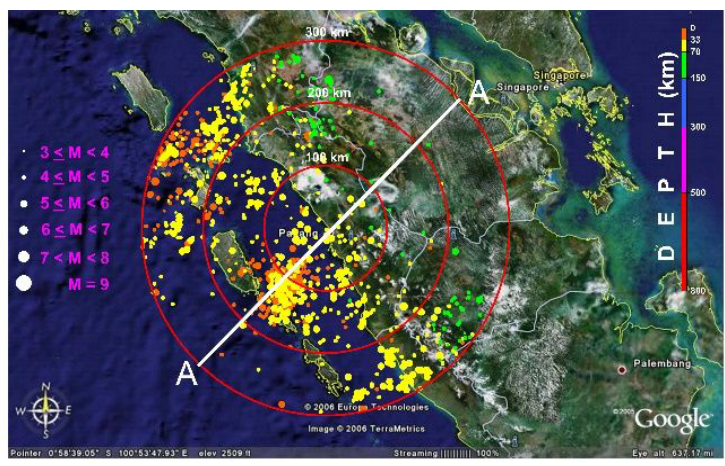

Fig. 4. Seismic data collected for cross-section through Padang City [5]

Based on the USGS report, the 30 September West Sumatera Earthquakes occurred at 17:16:09 has focus at $80 \mathrm{~km}$ depth and about $45 \mathrm{~km}$ from the city of Padang. Due to the medium deep earthquakes foci, the earthquake was suspected to occur at the subduction plate and causing damages in vast areas. The earthquake was recorded to have a peak acceleration of $0.28 \mathrm{~g}$.

Fig. 5. shows an illustration of the subduction phenomena west of Sumatera and the position of earthquake 'foci (Fig. 6.) confirms the movement of this plate from time to time. Due to these earthquakes, the whole west coast of Sumatera is threatened by earthquakes and tsunamis.

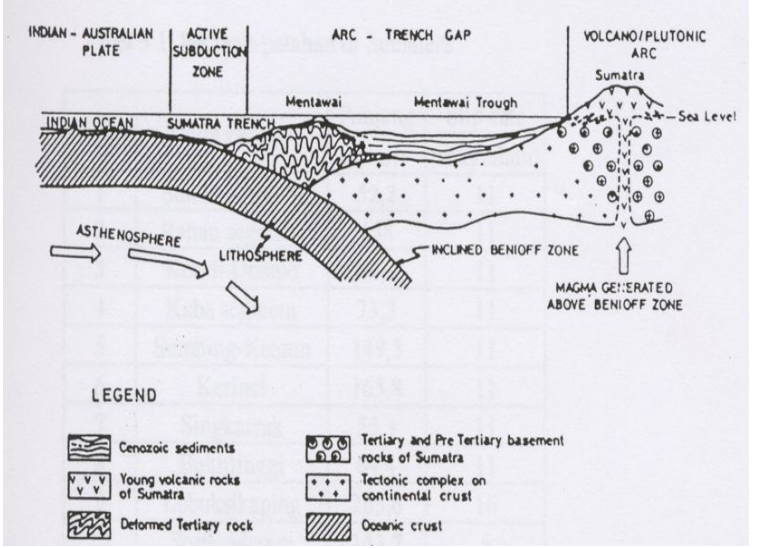

Fig. 5. Tectonic of West Sumatera 


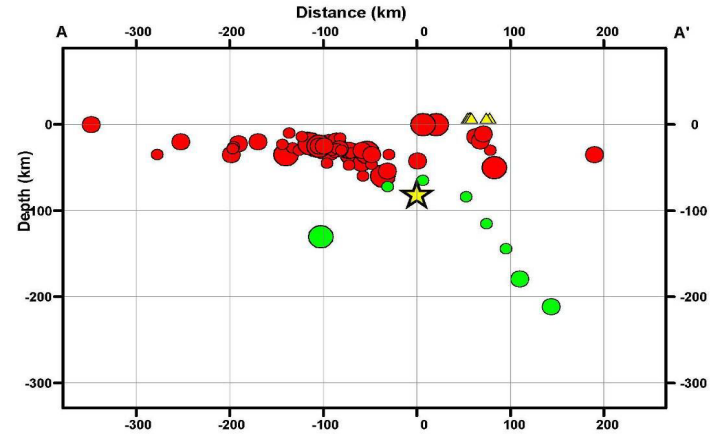

Fig. 6. Location of earthquakes 'foci confirm the mechanism of the subduction plate west of Sumatera island

\section{Prediction of possible tsunami for padang city}

The type of earthquake that produces tsunami is normally reverse faults. The movement of the IndoAustralian tectonic plate collides with the continental plate holding Sumatera in the form of a subduction zone (Fig. 7.).
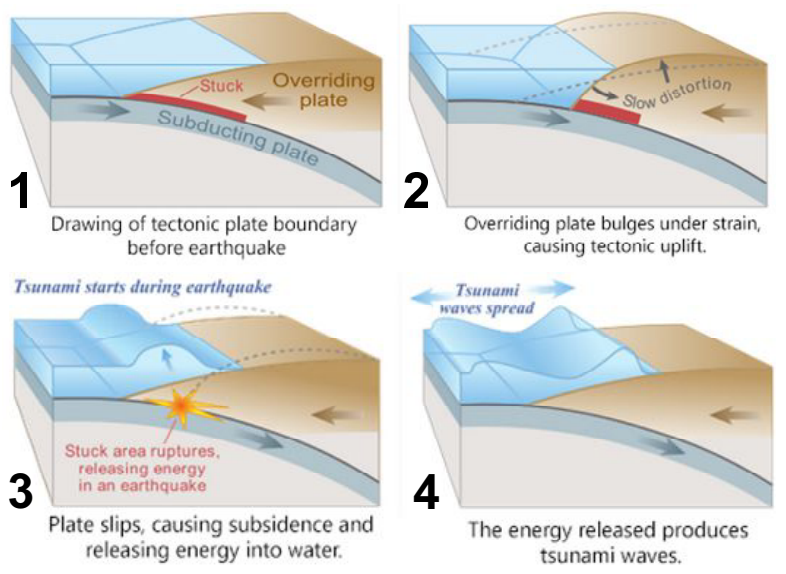

Fig. 7. Mechanism of tsunami

There has been a study on the possible earthquake source that might cause a tsunami in Padang based on the existence of seismic gap as shown in Fig. 8.

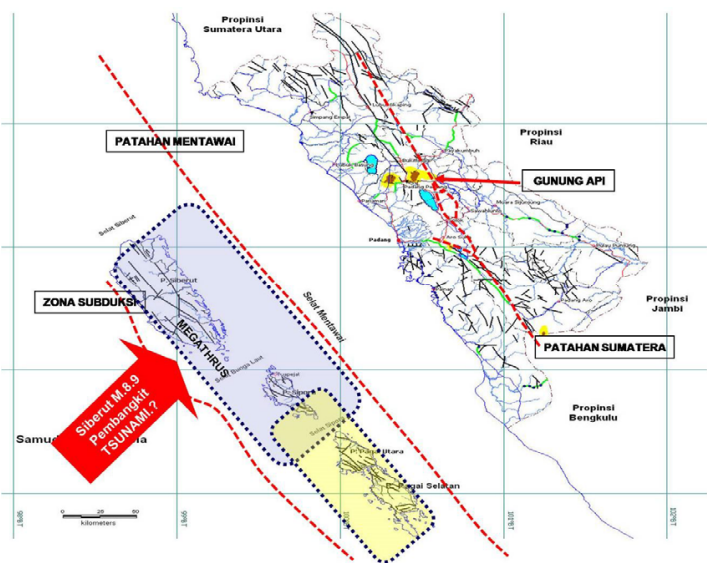

Fig. 8. The possible earthquake that might cause a tsunami in Padang [6]
National Geographic magazine (Indonesia edition) Edition I mentioned that West Sumatera Province specially Padang City has the highest risk of tsunami hazard from the fact of the dense population along the coastline of the city.

According to Executive Director of NGO TsunamiReady Community (KOGAMI), Patra Rina Dewi for the coastline of West Sumatera, as many as 534.878 people are subject to tsunami hazard in the red zone. The number of people is distributed into Padang City (380.402 people), South Coast (36.980), Pasaman Barat (29.649), Pariaman (25.029), Padang Pariaman (24.861), Agam (20.644) and Mentawai islands (17.313) [7]. The tsunami effect in Padang City, West Sumatera can be predicted with three earthquake moment magnitude (Mw) scenario; Mw 8.5, Mw 8.75, and $\mathrm{Mw} 9.0$ [2]. From the worst scenario, the result shows that the tsunami will strike the coastline of Padang City with an approximate time of only 15 minutes after the earthquake occurred. The predicted wave height is also calculated with an average height of $7 \mathrm{~m}$. Fig. 9. and Fig. 10. shows the location of Padang City and the predicted wave height at the sampling location. Reference [8] shows the prediction height of tsunami wave along the coastline, which predicted wave height can reach $15 \mathrm{~m}$ high. Fig. 11. shows the prediction of tsunami impacted area of Padang City.
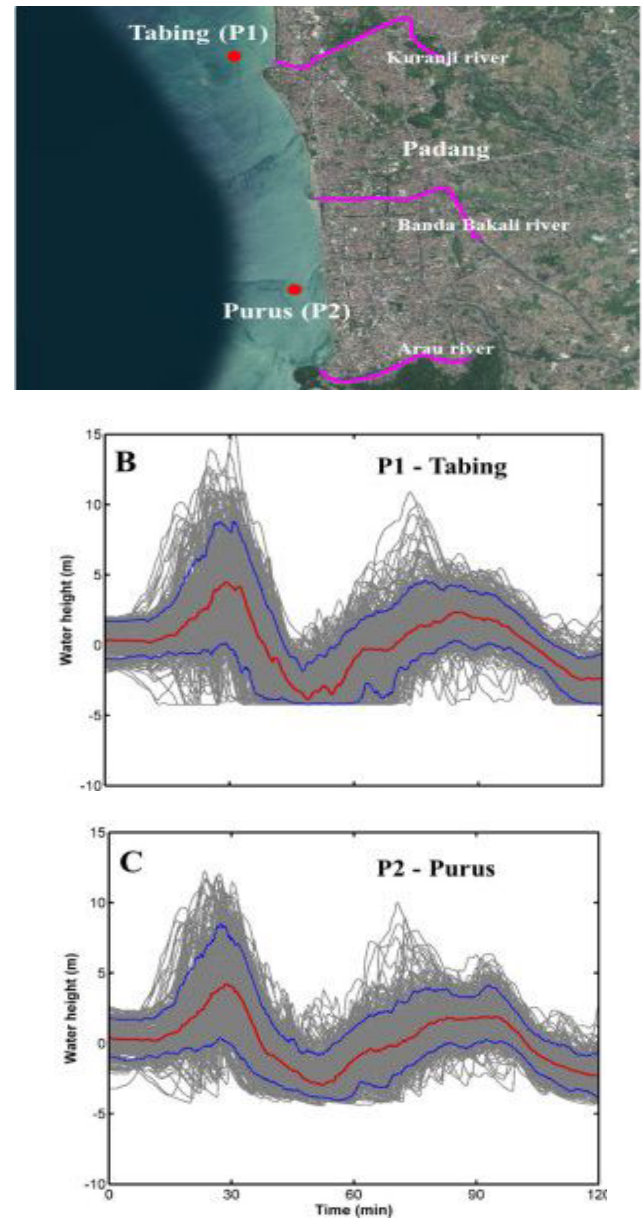

Fig. 9. Location of Padang City and predicted wave height $(\mathrm{Mw}=9.0)[8]$ 

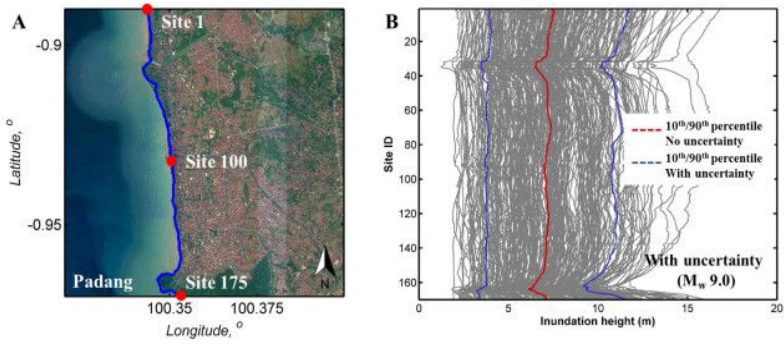

Fig. 10. Prediction of wave height along Padang City coastline [8]
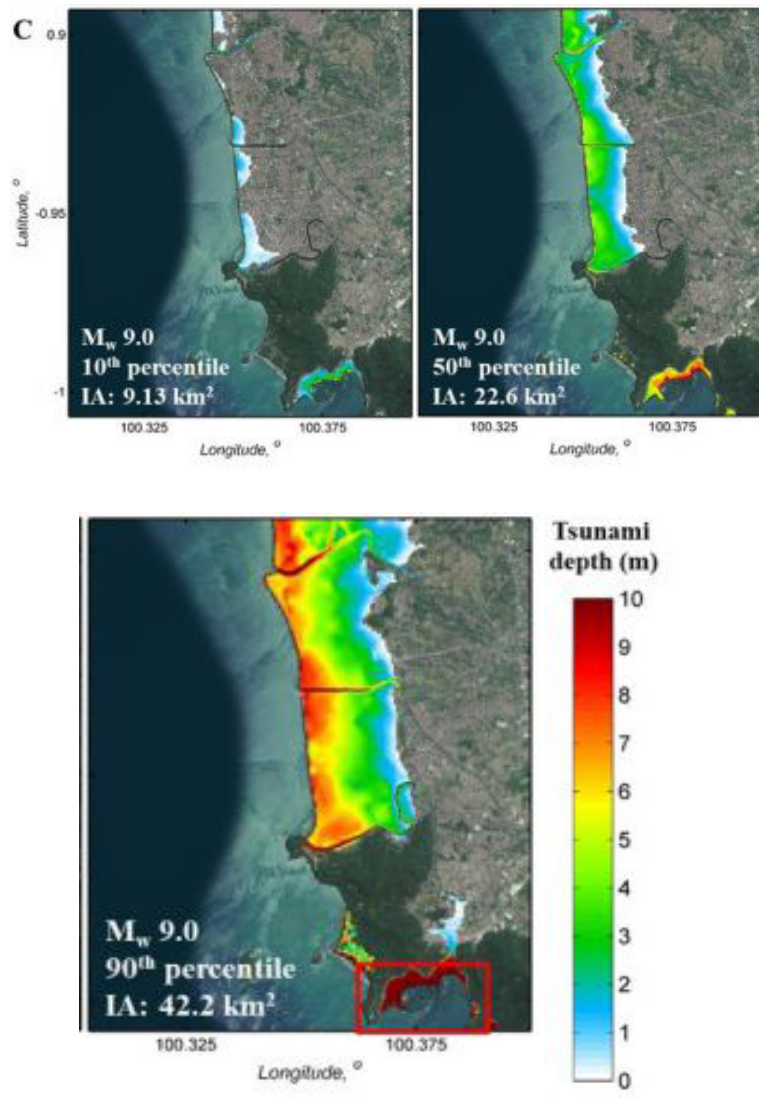

Fig. 11. Prediction of tsunami impacted area [8]

\section{The effects and prediction of The upcoming tsunami}

The effects of a tsunami on the Padang coastline can range from low to high destruction. It mostly depends on the characteristics of the seismic event that generated the tsunami, the distance of epicenters (earthquake origin) and its magnitude. The bigger the earthquake magnitude and the closer its epicenter to the coastline, the higher the destruction.

There are five major aspects of tsunami effects; the destruction, loss of life, disease, cost, and psychological effect. Most of these aspects give huge impacts on the human lives (see Fig. 12.).

The first aspect is the destruction caused by the tsunami when it strikes land. A large amount of water and wave energy can cause devastating property damage and loss of lives. The mechanism of destruction can be divided into two; the smashing force of a wall of water traveling at high speed, and the destructive power of a large volume of water draining off the land and carrying all with it.

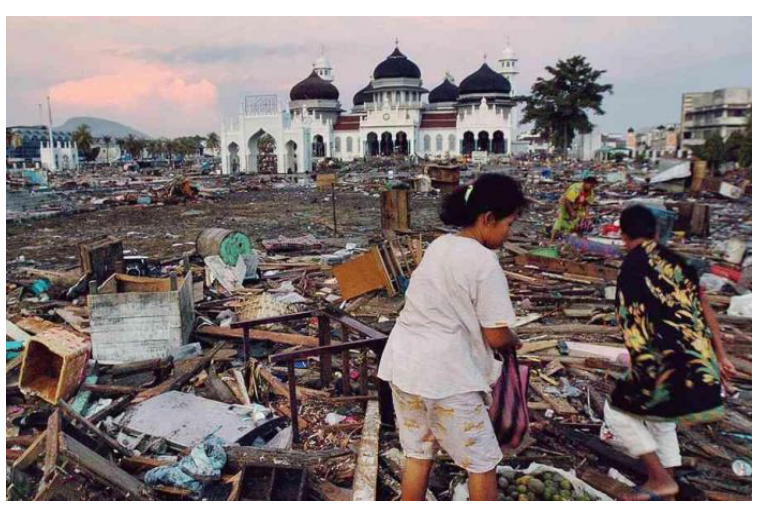

Fig. 12. The giant tsunami devastated Aceh 13 years ago

The second aspect is the loss of life. One of the biggest and worst effects of a tsunami is the cost to human life. Hundreds and thousands of people are killed by tsunamis. The cause of human death is not only being struck by tsunami wave and drowning but also from buildings collapsing, electrocution, an explosion from gas pipe, damaged tanks, and floating debris.

The third aspect is the disease, which is usually spreading during and after the flood. Illnesses arise when water is stagnant and contaminated. Under these conditions, it is very difficult for people to manage their health and for diseases to be treated. Therefore, infections and illnesses can spread very quickly and cause more loss of lives.

The fourth aspect is the cost, which is mostly the loss of property and cost of the reconstruction of buildings and infrastructures. It can't be denied that the destruction caused by the tsunami is extremely high cost. Infrastructure must be reconstructed, unsafe buildings must be demolished, and rubbish must be cleared. In addition, the local economy also needs a support to restart and re-developing.

Last but not least, the fifth aspect is the psychological effect. Victims of tsunami often suffer psychological problems which can last for days or years. People suffering from grieves and their depression of losing homes, businesses, and families. To restore this problem, a sustaining collaboration and cooperation between the government and the victim himself is a must.

\section{Liquefaction potential of the site}

Phenomena of liquefaction at the Padang City were in the form of sand blows at several sites, flow liquefaction causing lateral displacement and cyclic mobility. Those three phenomena causing settlement and loose of shear strength. In the lateral movement, the foundation might have shifted, and land cracks along laterally as shown in Fig. 13. 


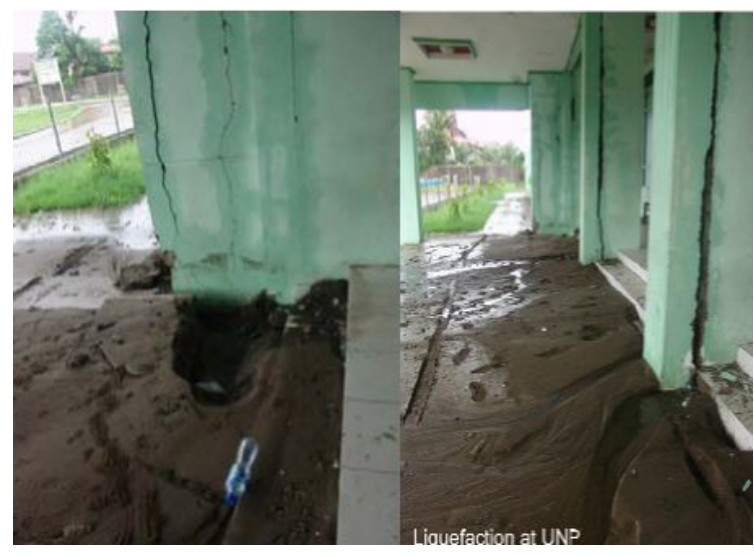

Fig. 13. Liquefaction phenomena at UNP (Padang Public University) (Hakam et al, 2009)

Flow liquefaction is well illustrated in the area of Samudera road at Padang city which is parallel to the shore. The Samudera Road was newly completed. The lateral flow liquefaction has caused a longitudinal crack as shown in Fig. 14.

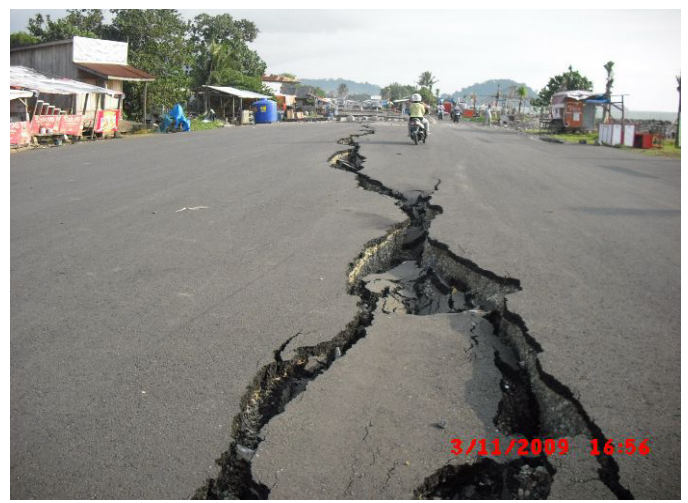

Fig. 14. Longitudinal cracks due to liquefaction flow failures at Samudera Road - Padang [5]

\section{Damages of infrastructure and buildings}

Other buildings investigated include the Padang Cathedral and Yos Sudarso Hospital. The investigation was intended to detect the mechanism of the failure and to be used for the design. It is of interest that most traditional buildings have been constructed using caissons system where concrete rings of diameter 80-120 $\mathrm{cm}$ were installed. Every ring is one meter high. Depending on the soil condition the depth of the concrete ring could be 3-6 m. The installation was done manually by digging the soils and let the ring sink down then add another ring. After the bearing layer is assumed reached, the rings are filled with concrete and sufficient rebar.

\section{Soil condition}

For assessment, drillings have been conducted. But the CPTu tests were also carried out due to the quick and accuracy of the results. We can determine shortly the soil stratification as well as soil consistency. The use of $\mathrm{CPTu}$ is also due to the repeatability of the results. Locations of the drilling and CPTu tests are shown in Fig. 15.

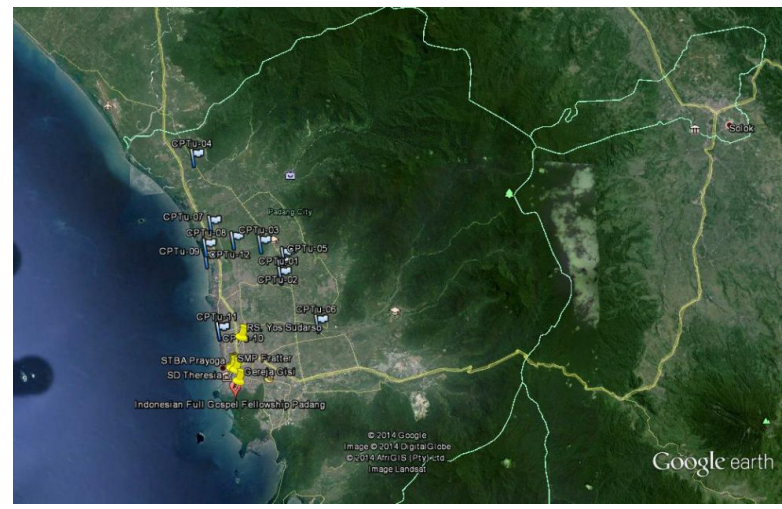

Fig. 15. Location of drillings and CPTu test

The objective of soil investigation is mainly to consider the liquefaction potential of the site considered for the seawall and also for buildings. The grain size has a major influence on the wash out of the soil against tsunami.

Experience in the Flores Earthquake (1992) and Banda Aceh (2004), both event created a miserable life for people. One important aspect of the failures are due to the erosion of the surface ground that mainly consisted of loose fine grain sands.

The results of drilling and grain size distribution of soil are shown in Fig. 16. and Fig. 17. An example is shown for the drilling at the location of the Padang Cathedral. From the drilling, it is shown that the first upper layer to $18 \mathrm{~m}$ consisting of loose to medium fine sands. This type of soil is very susceptible to liquefaction. Moreover, the depth of the water table is very shallow. If the seawall is to be constructed, the bearing capacity and potential of liquefaction shall be included for design consideration.

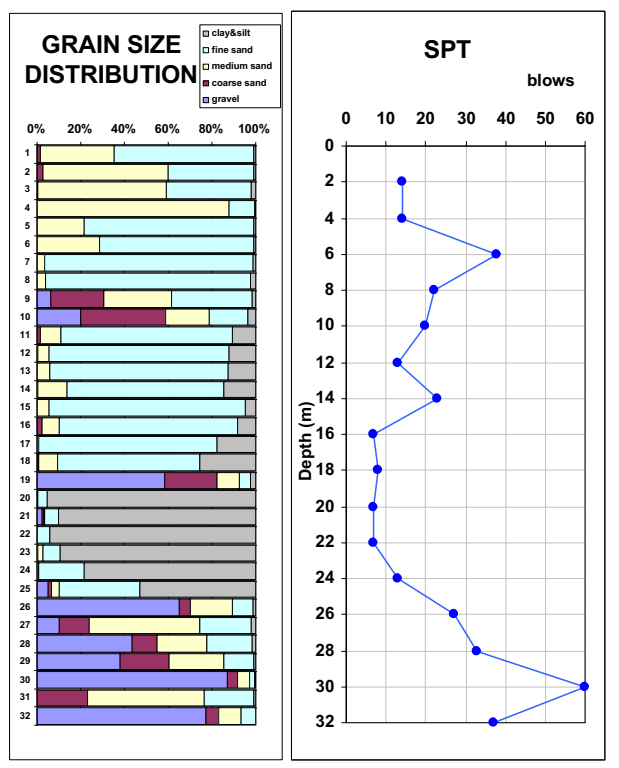

Fig. 16. Typical results of the soil stratification at Padang Cathedral (Rahardjo et al., 2012) 


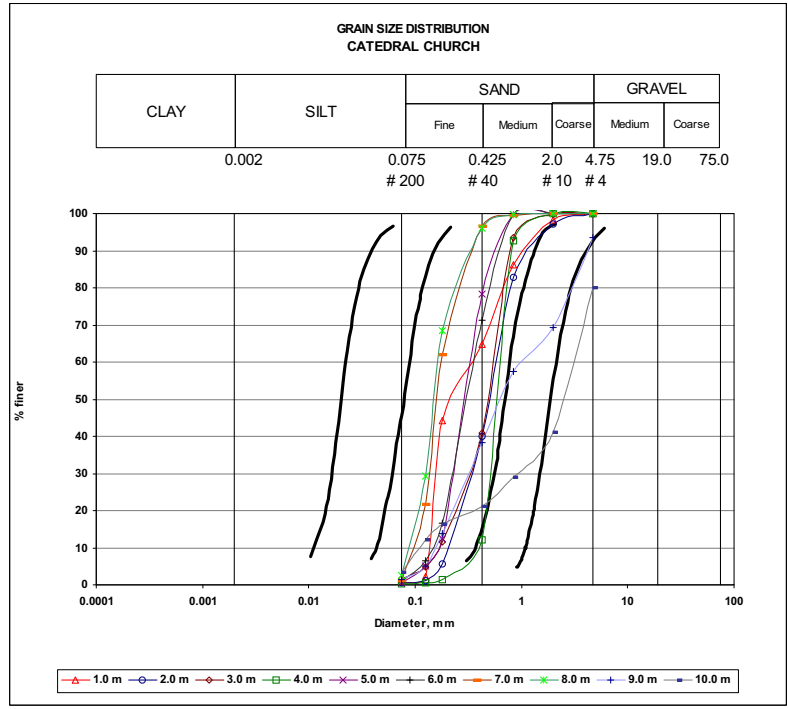

Fig. 17. Typical sandy grain size distribution in Padang (Rahardjo et al., 2012)

\section{Description of seawall}

A seawall (or sea wall) is a form of coastal defense constructed where the sea, and associated coastal processes, impact directly upon the landforms of the coast. The seawall protects the areas of human habitation, conservation and leisure activities from the action of tides, waves, or tsunamis. Seawalls may be constructed from various materials, most commonly reinforced concrete, boulders, steel, or gabions.

\subsection{Types of the seawall}

There are three main types of the seawalls: vertical, curved or stepped, and mounds. Vertical seawalls are built in particularly exposed situations (Fig. 18.).

Seawalls reflect wave energy. Under storm conditions, a non-breaking standing wave pattern can be formed, resulting in a stationary clapotis wave which moves up and down but does not travel horizontally. These waves promote erosion at the toe of the wall and can cause severe damage to the sea wall. In some cases, piles are placed in front of the wall to lessen the wave energy.
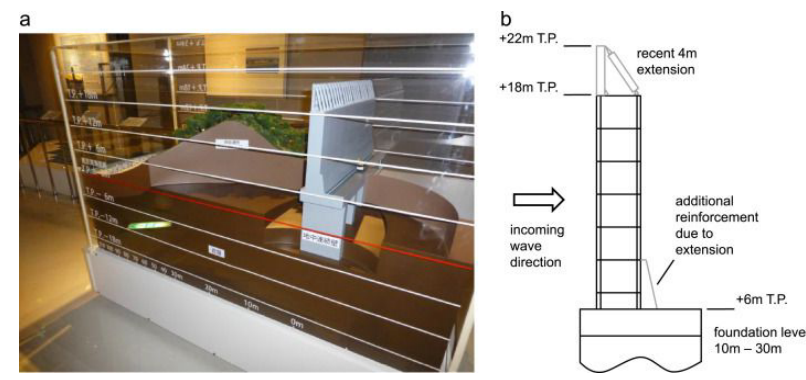

Fig. 18. Model of the vertical seawall in Japan being tested in the laboratory

Curved or stepped seawalls are designed to enable waves to break, to dissipate wave energy, and to repel waves back to the sea. The curve can also prevent the wave overtopping the wall and provides additional protection for the toe of the wall (Fig. 19.).

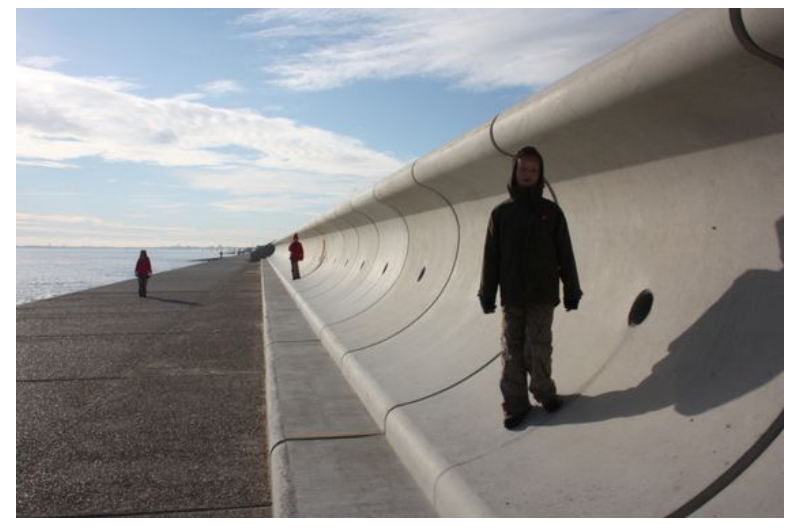

Fig. 19. Example of the curved seawall

Mound type seawalls, using revetments or riprap, are used in less demanding settings where lower energy erosional processes operate. The least exposed sites involve the lowest-cost bulkheads and revetments of sandbags or geotextiles. These serve to armor the shore and minimize erosion and may be either watertight or porous, which allows water to filter through after the wave energy has been dissipated (Fig. 20.).

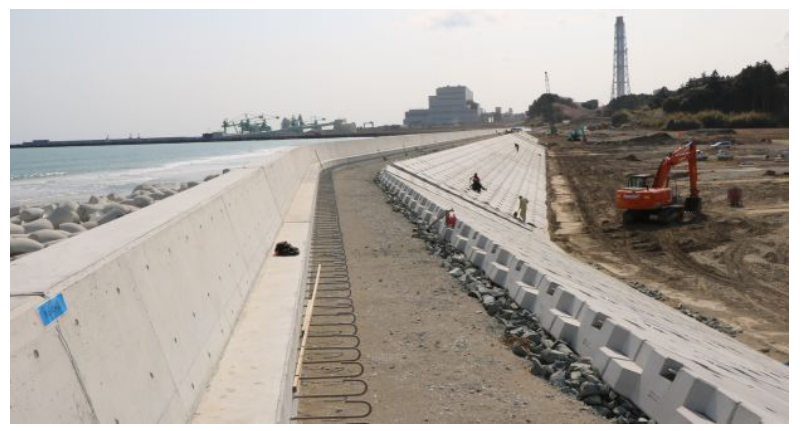

Fig. 20. Example of mound seawall

\subsection{Discussion on tsunami seawall for Padang City}

There are several ways to protect people from the tsunami. Evacuation route is the first alternative. However, for those who live near the coast, the tsunami will take place shortly, on the order of 15-30 minutes depending on the source of the earthquake. Short notice for tsunami warning system is not easy since people will be panic and the people movement could be chaos. The route may be effective if considering there are available for vertical evacuation.

Tsunami seawall is considered to provide an effective and feasible solution technically. The existence of the seawall will prevent the wave due to the tsunami into the area of Padang City. The seawall will be the primary protector of the people from the tsunami threat. The most important part, the tsunami seawall can prevent a number of victims caused by the tsunami. The local people will feel safer psychologically in Padang City. 
If the tsunami seawall is architecturally designed to have beauty, the seawall is not only a protective wall of tsunami threat but also functioned as a commercial and tourist area such as shopping centers, restaurants, cafes, etc. The beautiful architectural form of the seawall will make the area one of the main tourist areas in Padang. The commercial and tourist areas will attract investors to invest and the development of the area will increase the income and profit of Padang City.

Behind the walls need to be built roads as the main access. The main road can improve the citizen economy in the coastal area of Padang City. Along the west coast of Padang city is Samudra road, which should be considered an integral part of the seawall. If the seawall is designed for multifunction, then the tsunami seawall becomes a special icon of Padang City.

Besides the benefit of seawall for Padang City, there are also disadvantages that need to be considered. Based on studies conducted by experts in Japan, there are some things to note from the construction of this wall for the city of Padang. The presence of a tsunami wall will deter the coastal population to enjoy the beauty of the beach directly. Although there is direct access to the beach through the wall, the coastal atmosphere will change. Construction of the wall will change the masterplan from Padang City. Masterplan changes require a review because it will change the development budget of the government.

The cost of the seawall construction is very high. In addition, the operational and maintenance of the tsunami seawall requires costs as well. Therefore, the wall needs to be designed as a tourist and commercial area and financed by private parties in order to reduce the government's budget.

Based on the previous discussion that there is liquefaction potential in Padang City, there is no guarantee that the wall will be able to withstand the tsunami when the ground of the wall is experiencing liquefaction. Nevertheless, the wall becomes a wave energy damper so that damage to infrastructure in the city is not too fatal.

Although there are some disadvantages of tsunami seawall, the government should pay more attention to the safety of its citizens against the tsunami disaster.

\subsection{Innovation of tsunami seawall design for Padang City}

To reduce the construction, operational and maintenance costs that are too great for wall construction, the shape of the walls can be architecturally and add some function to the walls. When the disaster does not occur, the wall can be converted to a shopping, tourist area, and main road. The area will increase in local revenue and cover very expensive development costs.

Based on the previous discussion, the average tsunami height is about $7 \mathrm{~m}$. Therefore, the wall height is taken at $7 \mathrm{~m}$. To anticipate the runoff of water, it is necessary to install a rubber dam on the wall. The rubber can be developed up to $3 \mathrm{~m}$ in diameter. Fig. 21. shows a design sketch of the wall for Padang City and Fig. 22. shows the architectural view of seawall utilization for the commercial area.

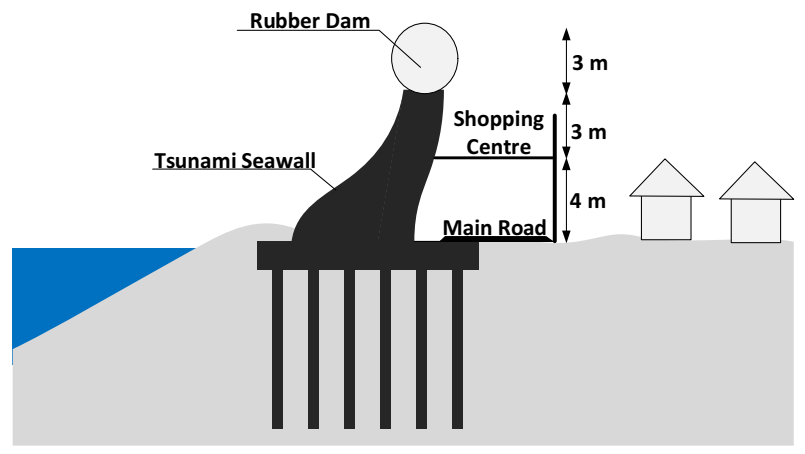

Fig. 21. The innovation of seawall design for Padang City

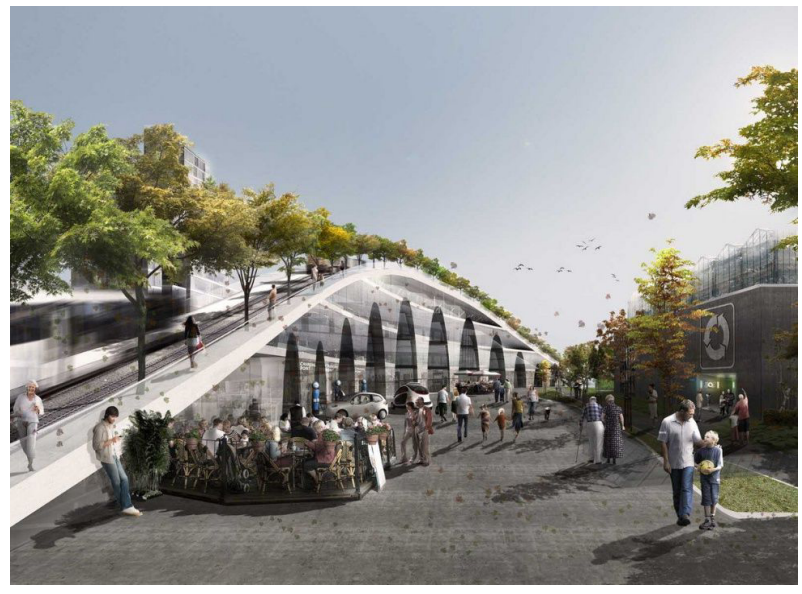

Fig. 22. Utilization of seawall for the commercial area

The authors would like to thank Universitas Katolik Parahyangan for enormous support to this paper.

\section{References}

1. P. P. Rahardjo., A. Sri Lestari, B. Widjaja, A. Lim, S. Rustiani, S. Herina, S. Wiguna, Geotechnical Research of Infrastructure Damages Caused by 30 September 2009 Earthquake (In Indonesian), Internal Report. Research and Community Service Agency (LPPM), Parahyangan Catholic University, (2010)

2. Wikipedia, (https://id.wikipedia.org/wiki/Berkas:Padang_City a s_seen from the peak of Gunung_Padang, 201702-14.jpg), accessed 20 April 2018

3. LIPI Geoteknologi (Indonesian Institute of Sciences Research Center for Geo-Technology), Research Report: Liquefaction Zoning for Padang City (In Indonesian). (2012)

4. D. H. Natawijaya, and K. Shieh, Tectonics and Seismicity of Sumatera, Journal of Geophysical Science, (2003)

5. P.P. Rahardjo, Geological Disaster: Lecture Notes (In Indonesian), Parahyangan Catholic University, (2008) 
6. Pusdalops BPBD Sumbar (Center for Disaster Management Operations of West Sumatera), (https://gempapadang.files.wordpress.com/2011/07/ kerawanan-geologi-sumbar.jpg), accessed 20 April 2018

7. A. Amarullah, Caution: Padang has the highest tsunami risk in the world (In Indonesian), (https://www.viva.co.id/berita/nasional/121967awas-padang-berisiko-tsunami-tertinggi-dunia), accessed 15 April 2018

8. A. Muhammad, K. Goda, N. A. Alexander, W. Kongko, and A. Muhari, Tsunami Evacuation Plans for Future Megathrust Earthquakes in Padang, Indonesia Considering Stochastic Earthquake Scenarios, ACCEPTED in Nat. Hazards Earth Syst. Sci. Discuss., https://doi.org/10.5194/nhess-201775, 2017. 